\title{
Minor Salivary Gland Mucoepidermoid
}

\section{Carcinoma}

National Cancer Institute

\section{Source}

National Cancer Institute. Minor Salivary Gland Mucoepidermoid Carcinoma. NCI

Thesaurus. Code C5953.

A carcinoma that arises from the minor salivary glands. It usually presents as a firm and painless mass. It is characterized by the presence of epidermoid cells, mucus producing cells, and cells of intermediate type. The majority of cases have a favorable outcome. 